\title{
Functionalization of Crumb Rubber Surface for the Incorporation into Asphalt Layers of Reduced Stiffness: An Overview of Existing Treatment Approaches
}

\author{
Christina Makoundou ${ }^{1, *} \mathbb{C}$, Kenth Johansson ${ }^{2}$, Viveca Wallqvist ${ }^{2}$ and Cesare Sangiorgi ${ }^{1} \mathbb{C}$ \\ 1 Department of Civil, Chemical, Environmental and Materials Engineering, University of Bologna, \\ 40131 Bologna, Italy; cesare.sangiorgi4@unibo.it \\ 2 Department of Material and Surface Design, Research Institutes of Sweden (RISE), 11428 Stockholm, Sweden; \\ kenth.johansson@ri.se (K.J.); viveca.wallqvist@ri.se (V.W.) \\ * Correspondence: ngongo.makoundou2@unibo.it; Tel.: +39-05-1209-0215
}

check for updates

Citation: Makoundou, C.; Johansson, K.; Wallqvist, V.; Sangiorgi, C.

Functionalization of Crumb Rubber Surface for the Incorporation into Asphalt Layers of Reduced Stiffness: An Overview of Existing Treatment Approaches. Recycling 2021, 6, 19. https://doi.org/10.3390/ recycling6010019

Received: 22 January 2021

Accepted: 3 March 2021

Published: 8 March 2021

Publisher's Note: MDPI stays neutral with regard to jurisdictional claims in published maps and institutional affiliations.

Copyright: (c) 2021 by the authors. Licensee MDPI, Basel, Switzerland. This article is an open access article distributed under the terms and conditions of the Creative Commons Attribution (CC BY) license (https:// creativecommons.org/licenses/by/ $4.0 /)$.

\begin{abstract}
The substitution of mineral aggregates with crumb rubber (CR) from waste end-of-life tires (ELTs) in the asphalt concretes, has been considered a sustainable paving industry approach. The rubber has been used to construct pavements with proven enhanced resilience and improved durability. However, some issues related to the rubber's surface adhesion or swelling may arise with these practices and generate complications (binder consumption, temperatures, mixing times). One possible solution to overcome the materials' compatibility problems is to pre-treat the CR's surface before its incorporation into the asphalt mixes to allow a surface functionalization that can enhance coverage and cohesion inside the mixes. The physical treatments using radiations-based beam are already exploited in the plastic recycling industries avoiding the use of chemicals in considerable amounts. Such treatments permit the recovering of large quantities of polymer-based materials and the enhancement of interfacial properties. This article provides an overview of existing surface treatments of polymers and especially rubber, including gamma ray, UV-ozone, microwaves, and plasma. Several studies have shown an overall improvement of the rubber surface's reactive properties due to contaminant removal or roughness enhancement attributed to cross-linking or scission reactions occurring on the rubber's surface layer. With those properties, the asphalt mixes' phase stability properties are increased when the pre-treated rubber is incorporated. The treatments would permit to increase the CR quantities, yet reduce the layer stiffness, and improve the durability and the sustainability of future advanced road pavements.
\end{abstract}

Keywords: end-of-life tires; crumb rubber; surface treatment; functionalization; asphalt binder; low-stiffness asphalt concretes; dry process; pavements

\section{Introduction}

The environmental issues related to the quantities of waste rubber and plastics on the planet are perpetually increasing. One of the most common wastes arising from the transportation industry is end-of-life tires (ELTs). Undeniably, large quantities of rubber can be found in household appliances. However, the described evolution is mainly due to the increase in the world population, thus increasing vehicles' production: the transportation market represents $63 \%$ of rubber use. Every year, nearly 3 million tons of waste tires are generated in Europe, of which approximately 2 million tons are either recycled or recovered, as reported by the European Tyre \& Rubber Manufacturers' Association. Composed in the majority by highly engineered rubber, the non-biodegradable stage of the final tire product is involved in several waste management problems [1,2]. ELTs usually enter a waste management system based on recycling the constituent materials and the recovery of energy by controlled combustion, and still, in some countries, on the landfilling in vast land surfaces. 
In terms of recycling, many industries in the field of construction materials and other engineering fields use CR from ELTs in various forms for applications such as rubberized asphalt concretes [3-5], non-structural materials, especially for thermal and acoustical insulation [6,7], as well as playgrounds and artificial turf surfaces [8,9]. Indeed, the ELTs rubber benefits are well-known in civil engineering, particularly in the road pavement sector, since the first rubberized asphalt was produced in the last century. The elasticity of rubber has been proven to positively influence the mechanical performance, i.e., the pavement layers' durability, while its low stiffness can contribute to abate the noise generation [2]. As a matter of fact, in the latest years, the CR obtained from ELTs following different possible processes has been proven to be an efficient solution to reduce the accumulation of waste tires while contributing to the sustainability and carbon footprint reduction of road transport $[3,10,11]$.

However, ELTs' rubber is not the only component involved in the mix-design of rubberized asphalt mixtures. Generally, when the rubber addition or substitution query occurs, the level of interaction between the rubber particles and asphalt binder during the production (either wet or dry) and laying processes can bring issues in terms of workability and emissions. These issues are particularly experienced when the ratio between the rubber and aggregate quantities is high. Depending on the time and temperature of the mentioned interaction, the rubber particles are known to swell in asphalt by adsorbing the bitumen's lightweight components [12]. The small molecular size of maltenes diffuse inside the rubber particles, and rubber volume expands [3]. The described phenomenon is not happening just because of each component's chemical properties; the size distribution of rubber and, mostly, the time and temperatures of interaction have a considerable effect on rubber swelling within the asphalt binder. The swelling of rubber particles can change the volumetric proportions of the components in the mixture and modify the structure of their close bonds and, hence, alter the properties of the final asphalt layer. To counteract this phenomenon, several methods aiming to control the swelling behavior of rubber exist. The addition of chemicals to the mixture [13,14], the possible devulcanization [15-18] or, last but not least, the surface treatment of the CR employing physical or chemical procedures $[1,19-23]$ are some of the most frequent solutions. The rubber's surface treatment represents an evolving method, preferably used when the dry incorporation method is adopted.

This review aims to describe the contribution of possible physical surface modifications of rubber on the enhancement of its properties for the use in road engineering materials including modified binders and asphalts pavements.

\section{Rubber Tires and Their Use in Asphalt Pavements}

\subsection{History and Waste Management of Tires}

Originating from Charles Goodyear's discovery of the vulcanization of rubber in 1839- the process of transforming the rubber with sulfur and heat to reinforce the rubberand from John Boyd Dunlop's invention of the pneumatic tire in 1888 [24], tires became a fundamental piece of the economy of every nation that relies on the transportation of goods and people on rubber.

The development continued when in 1891, the Michelin brothers made it removable from the rim. As a result of these discoveries, tires can be recycled, and nowadays, used tires are regularly retreated, potentially reused, or recycled to promote the circular economy of the product and its constituents, save costs for the domestic economies, and preserve the environment.

Undeniably, tires' composition and design differ by category (i.e., passenger vehicle, utility vehicle, truck, etc.,) or manufacturers. However, it always includes four primary material groups: rubber, carbon blacks/silicas, material reinforcement, and facilitators. Figure 1 shows the common tire constituents and the generic weight composition for the passenger car and trucks vehicle [25]. Tires contain a mixed composition of both natural and synthetic rubber compounds, which are the primary materials used in tires' produc- 
tion as they are crucial to meet the safety performance and environmental requirements. Unfortunately, rubber usage also has effects on land space consumption that can cause degradation and loss of natural habitats due to the required Hevea tree exploitation [24].

Altogether, the wastage and recycling of polymer-made products have attracted considerable public attention owing to a broad concern about climate change, and the percentage of rubber recycled in the European Union (EU28) was found to be $91 \%$ in 2018 [25]. Therefore, it is clear that in the EU, there is still excellent room for exploitation as far as tires and rubber recycling is concerned [26].

Nowadays, while being recycled, the materials from waste tires can be recovered or sorted and reused employing different processes: ambient or cryogenic shredding, and thermal pyrolysis (Figure 1). The ELTs are regularly reprocessed in other material design applications and should be considered like newly engineered products for roads or building construction, sports equipment or clothes and fuel [26]. Fabrics, steel, and especially the rubber contained in the tires can be recycled in different form to replace the raw constituent materials, hence reducing the extraction of resources, land use, greenhouse gas (GHG) emissions, pollution, and water consumption. Additionally, the whole ELT structure can have an essential role in other fields of applications as shown in the Figure 1.

One of the most central materials recycled from ELTs is the rubber. It can be shredded and marketed in small particles (chips, coarse, powder) which are used in artificial grass, playgrounds, surfaces for horseback riding, asphalt pavements, and safety or acoustic barriers, among many other uses $[25,27]$.



Figure 1. Different rubber recycling processes and potential applications (adapted from European Tyre Recycling Association, Rubber Manufactures' association, Swedish Tyre Recycling Association).

Using the ELTs material reduces the need to extract and produce new raw rubber for other applications and foster the circular use of resources. The final objective of ELTs recycling, as illustrated in Figure 1, is to be able to use the newly produced material through different applications depending on the shape [24]. 


\subsection{Properties of the Recycled Rubbers}

The physical properties of ELTs rubber depend on the adopted recovering process (Figure 1) and have an essential role as far as the subsequent use of those materials is concerned [3,28-30]. Despite the sorting process, the various sources of tires and the vulcanization reaction can generate utterly different rubber granulates from a chemical and physical point of view. Also, the reprocessing can itself create variation, particularly concerning the rubber particles' surface characteristics [8,9].

Starting from their manufacture, tires are made of highly engineered material. If recycled as constituent material in other applications, they will require an evaluation of several properties to be conducted to cope with its new use and assess the non-hazardousness for new goods production. Thus, typical properties, including geometrical and structural properties, elemental characterization, and dust or chemical leaching assessments, among others, are evaluated to meet the health and safety specifications and produce sustainable products with RR. The rubber's chemical composition can also be diagnosed through a representative sample and can be used to study the rubber's compatibility with other components while reusing it for new applications. Crucial data are related to the measurement of polycyclic aromatic hydrocarbons (PAHs) to protect the environment, the workers, and the users from possible noxious emissions, during and after the manufacturing processes. Leaching of the rubber should remain at a very low value as for food or water production values. A possibility to decrease this value using treatment will assess a significant improvement.

\subsection{The Use of Recycled Rubber in the Road Construction Sector}

\subsubsection{Wet and Dry Processes in Asphalt Pavements Applications}

Rubber chips, powders, or crumb particles have been used for many years worldwide in road pavements. They are known for their effectiveness in designing low-noise pavements or in fatigue-resistant asphalt applications owing to the residual elastic properties [7]. In addition to the improvement regarding the circular use of materials, the aim of using ELTs rubber in the asphalt pavement was to improve the performance of the already existing pavements or reach comparable values but also develop innovative materials [30]. In fact, the incorporation of CR in substantial amounts can decrease the layers' stiffness and increase the pavement's overall performance while improving the ELTs waste management impact $[3,28,29]$.

To produce a rubberized asphalt, aggregates, rubber (chip, crumb, powder), and bitumen must be mixed. Two well-known processes were and are generally used: the wet and the dry process. During the wet process, the rubber is first mixed and blended with the bitumen at high temperatures as described in Zanetti et al. studies [28]. This process provides several technical and rheological advantages to the bitumen including improvement regarding fatigue and rutting resistance [31]. However, it needs high temperatures (not less than $170-175^{\circ} \mathrm{C}$ ), continuous agitation, and prolonged contact time between rubber and bitumen to produce a rubberized bitumen before adding the aggregates $[3,28]$. The second process is known as the dry one. The rubber substitutes a portion of the aggregate mix gradation. $\mathrm{CR}$ are added to aggregates and heated in the mixer before adding the binder. Mixing temperatures are generally lowered $\left(160^{\circ} \mathrm{C}\right)$, but a short contact time between the rubber and the binder is preferable in better control of the rubber's binder absorption. Compared to the wet process aiming to enhance the binder's elastic properties, rubber particles' leading role in the dry process is to fill spaces between aggregates and provide an elastic buffer between the mineral aggregates' skeleton. Improvement of skid resistance was also recorded by using the last-mentioned process. Furthermore, even if the moisture resistance can be decreased [31], the dry method is appreciated for its positive environmental issues improvement as it can use lower temperatures, and permits the addition of larger shapes and quantities of rubber in the mixture, thus recycling more tires $[3,28]$.

Each process has advantages and disadvantages and can be used for different applications. In principle, the primary condition of rubberized mixture design is evaluating the 
rubber and the binder properties separately, but it is also crucial to assess how they interact within the mixture.

\subsubsection{Rubber-Binder Interaction}

For many years, rubber-bitumen interactions are the central aspect of rubberizedasphalt investigations. Indeed, rubber and bitumen chemical and surface properties present specific interactions that can modify their structure, as explained in Hassan et al., Zanetti et al., and $\mathrm{Li}$ et al. $[3,28,30]$. The role of bitumen in these interactions is predominant as the exchange of oils depends on its chemical nature, bearing in mind that the binder must coat the aggregates for adhesion first.

As it can be found in the studies mentioned above, the diffusion of bitumen fraction into the rubber, the swelling reaction, happening either with the wet or the dry process, seem to be the significant reaction occurring during mixing. This reaction occurs depending on the CR (chemistry, shape) and bitumen properties.

In fact, a diffusion phenomenon happens when a rubber particle is in contact with the liquid bitumen. When this contact starts, the rubber absorbs some of the bitumen fractions, namely the lighter ones. The small molecular size of maltenes permits their diffusion in the rubber particles; consequently, rubber volume expands [3]. The chemical properties of the bitumen are one of the causes of this phenomenon. The higher the penetration grade is, the higher amounts of maltenes are available and the swelling tends to increase. However, the described phenomenon did not happen just because of the chemical properties of each part. The size distribution of rubber, rubber surface characteristics, time, and interaction temperature significantly affect rubber swelling within the bituminous mix.

For instance, more bitumen fractions can be incorporated inside the rubber particles via their porosities with a long time of contact. Finally, the surface texture has a substantial effect on the swelling phenomenon.

Undeniably, the RR's surface type and specific area has a vital role in the final mixture behavior. Therefore, any modification to the surface properties could affect the rubber's swelling behavior and, consequently, the final mixture's rheological properties. In the light of the above, rubber pre-treatments should be able to modify the surface properties to control the swelling phenomenon connected to the migration of light fractions from bitumen to rubber, without compromising the elasticity of the rubber or the adhesion between the rubber, the bitumen, and the aggregates.

\section{Surface Treatments and Their Effect on Rubber-Bitumen Interactions}

\subsection{Surface Modification of Polymers}

Polymers such as rubber are generally inherently hydrophobic, low surface energy materials, and thus less prone to adhere to other substances. Adhesion improvement is the most common use but other surface characteristics, such as wettability, porosity, waterand chemical resistance, and moisture transmission are also addressed [32,33].

Two distinct types of modification exist as two main categories: physical and chemical modification. The first can also be divided into two groups, the first involved with chemical alteration of the surface layer, while the second with external layer deposition on the polymer material. The chemical modification consists of modifying the chemical composition of polymer surfaces either by direct chemical reaction or by the creation of covalent bonds with the chemicals [34].

Many types of polymers, like the rubber are commonly treated before subsequent processing. A wide range of methods, from treatment made using vacuum to atmospheric pressure, wet to dry, simple to sophisticated, and inexpensive to very costly to obtain the required functional characteristics of polymers exist [33,34].

This review aims to discuss a set of developed methods for the pre-treatment of rubber polymer to overcome the surface reaction issues and improve the adhesion ability between rubber, binder, and aggregates in a rubber concrete asphalt mixture. The environmental 
impact and the uncomplicated nature of the adopted methods are crucial parameters (Figure 2).

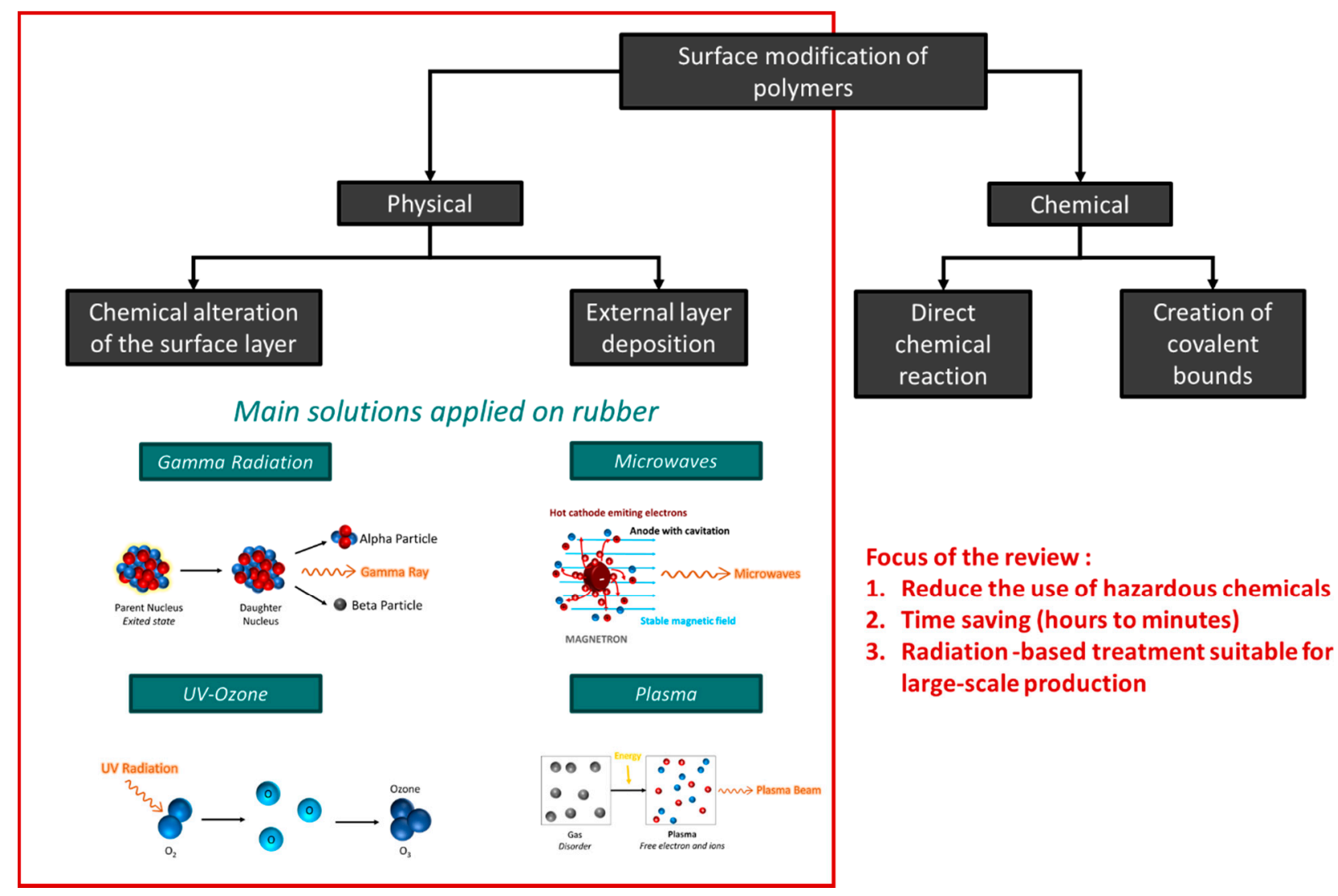

Figure 2. Scheme of the different possible treatment methods and the main solutions described in this review (adapted from $[22,35-45])$.

\subsubsection{Gamma Radiation}

Gamma-ray is an electromagnetic radiation that results in the disintegration of radioactive atomic nuclei and the decay of certain subatomic particles (alpha and beta) as shown in Figure 3a. Gamma ray is a highly penetrating electromagnetic radiation with very short wavelengths (few tenths of an Angstrom), and very energetic (greater than tens of thousands of electron Volts) [46]. This reaction is generally initiated in nuclear reactors. This reaction can be made at lab scale (Figure $3 b$ ) or industrial scale (Figure $3 c$ ) to treat large quantities of materials [37,47].

The gamma radiation is used successfully for several years to improve the properties of recycled polymer-based materials, including the rubber [47] and can cause change on polymers chemical structure and mechanical behavior. These modifications occur due to reorganization of bonds, which allows an increase in the degree of cross-link or reticulation (Figure 4). Several polymers (recycled or not) have been modified to optimize properties and increase their overall compatibility [48]. Such technology is feasible from both an ecologic and economic point of view as it can be applicated in large quantities of materials at lower costs.

Its main effect is the creation of possible cross-link improving the recovering of polymers; scission producing low molecular masses able to be used as raw materials or inducers, or chain branching including advanced polymerization to design more environmental friendly materials that can increase, decrease, or consolidate the original polymer's structure [23,33,48-51]. 

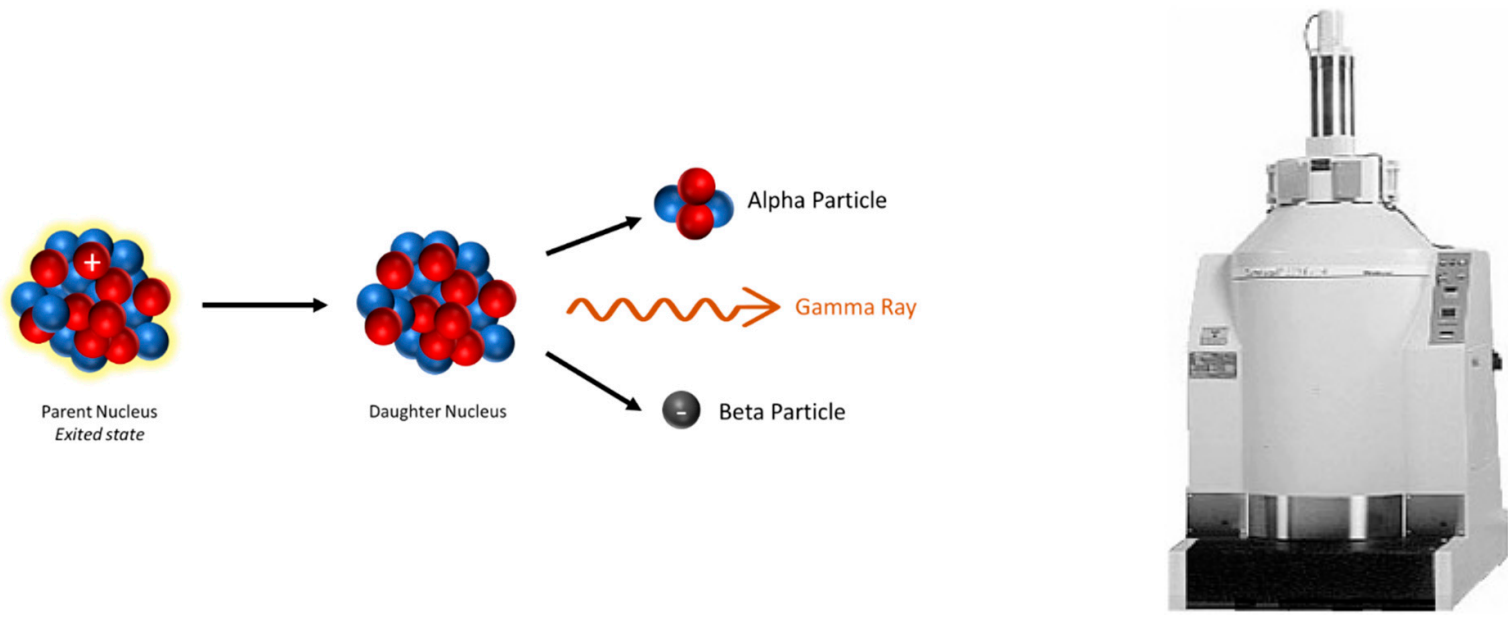

(a)

(b)

\section{Commercial Irradiator}

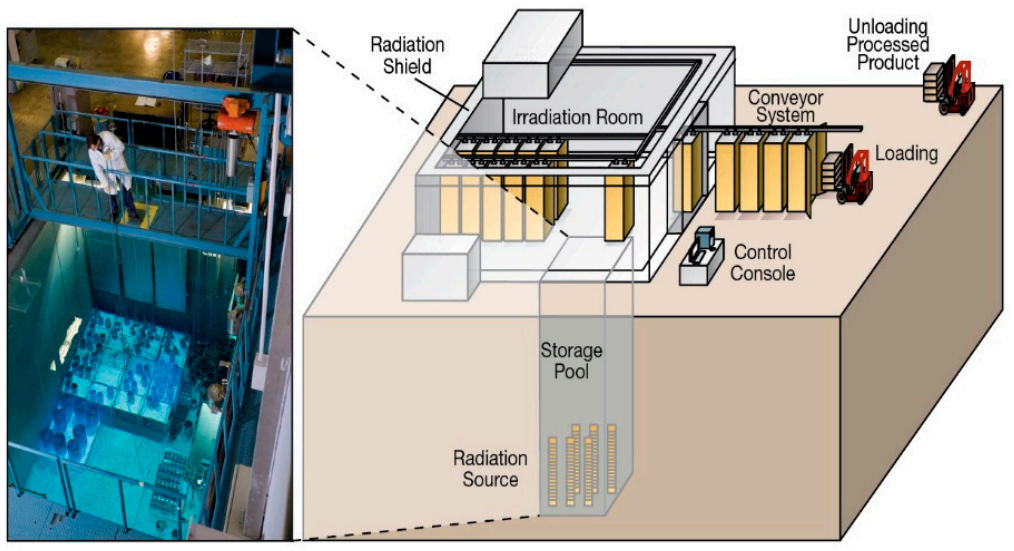

(c)

Figure 3. (a) Simplified scheme of the gamma ray initiation; (b) picture of a GammaCell 220 instrument designed for lab work Nordion ${ }^{\mathrm{TM}} ;$ (c) scheme of a commercial irradiator designed for industrial scale work Nordion ${ }^{\mathrm{TM}}$.

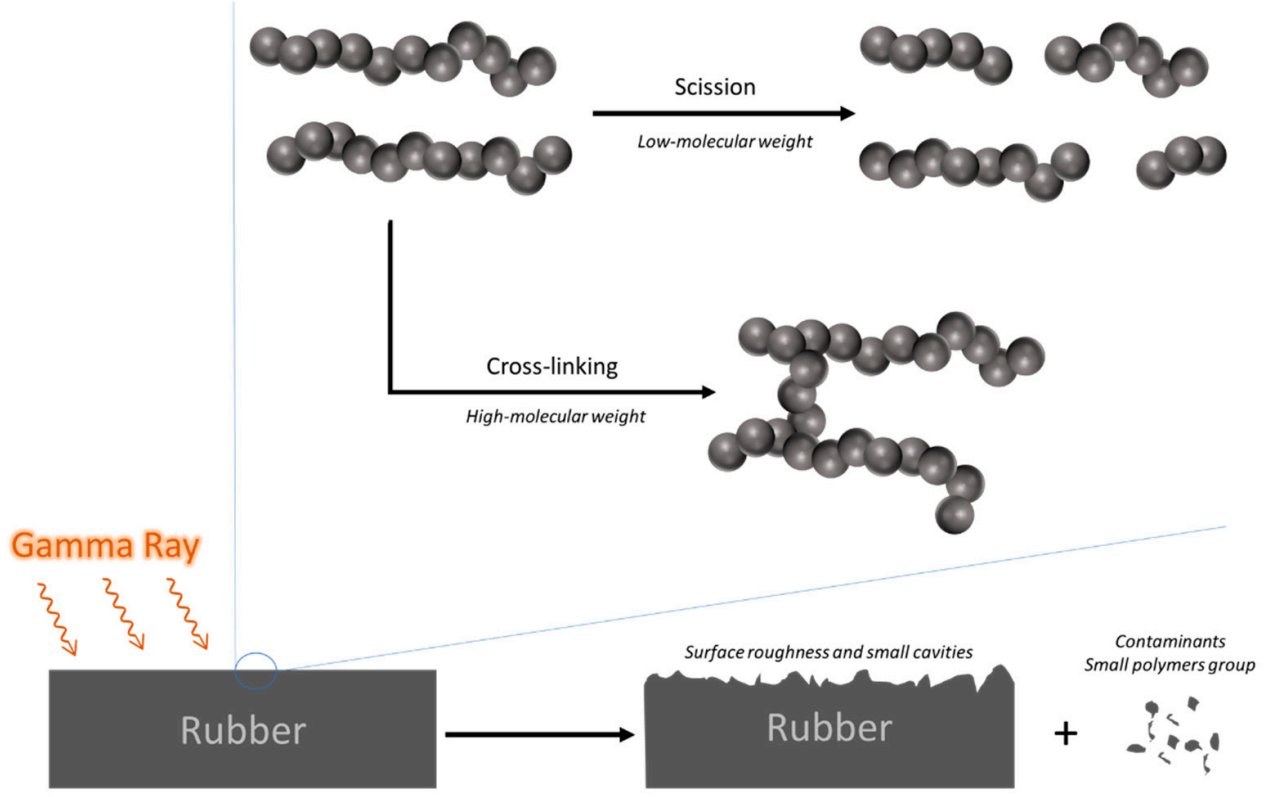

Figure 4. Simplified scheme of the gamma ray reaction initiation and effect on rubber surface. 
In a specific study, Faldini et al. [52] examined the irradiation of crumb rubber samples at several levels of absorbed radiation doses (100-1000 kGy). The samples were characterized by thermal analysis including differential scanning calorimetry (DSC) and thermogravimetric analysis (TGA), infrared (IR), and UV-visible spectroscopy (UV-Visible) and scanning electron microscopy (SEM). Through the analysis, same tendency was observed in several various case studies $[23,47,52,53]$. The SEM evaluation has shown the increase of the roughness, small cavities, and cracks on the surface when the irradiation increases. The higher is the gamma radiation absorption, the higher is the roughness. However, the spectroscopy analysis confirms the non-alteration of rubber's chemical structure.

The research from Chen et al. [54] discussed the effect of gamma ray on recycled and vulcanized butyl-rubber-based damping materials irradiated at doses from 10 to $350 \mathrm{kGy}$. When the absorbed dose increases, the chain scission reactions are stronger and conduct to decrease molecular weight and small decomposition [51]. These degraded low-molecular weight compounds made the rubber softer with increasing absorbed dose. A reduction of surface porosity is also observed without impacting the roughness.

In the studies of Martínez-Barrera et al. [53], the CR irradiated the gamma rays at 200, 25, and 300 kGy. Two significant improvements are observed when mixing the irradiated particles to concrete. Apart from the size of particles showing the effectiveness in increasing the softness of the concrete, the rubber particles' irradiation could permit the use of more tire particles and reduce the use of raw materials. Thus, high irradiation doses produce physicochemical changes on the $\mathrm{CR}$ particles, mainly cross-linking polymer chains, allowing high physical interactions with the concrete components. The irradiation on particles at $300 \mathrm{kGy}$, by initiating surface roughness and cracks due to cross-linking reactions, improves the elastic modulus and the deformation of the concrete-based sample, the material is more flexible. Gamma rays generate cross-linking of polymer chains on the rubber, which restricts the movement of their molecules. Then, weak interfacial interactions are produced in the cement in this case.

In the work of Ibrahim et al. [23], the irradiated rubber was mixed with an asphalt binder. The anti-aging performance was evaluated through the rolling thin film oven test (RTFOT) in terms of subsequent penetration, softening point, ductility, weight loss, viscosity, etc. The results showed that the bitumen samples using $10 \%$ of $\mathrm{CR}$ irradiated at $300 \mathrm{kGy}$ had high-temperature stability, low-temperature ductility, and the anti-ageing performance improved. The rheological studies also illustrated that the modified bitumen with CR irradiated at $300 \mathrm{kGy}$ has the most considerable properties and the rubber is better dispersed into the binder [23].

Previous investigations [51] have shown that low dose (from 0-70 KGy) leads to cross-linking after a long time of exposition and less scission while higher doses (more than 70 and from $300 \mathrm{kGy}$ in Ibrahim et al. study) leads to both reactions with a stronger scission. The result of those reactions is the formation of softer and more viscous rubber with a rough surface that eases the adsorption among others component in the mix. A gain in stability of the asphalt mixes is shown with the use of gamma rays. The irradiation increases the compatibility of the components.

All the studies summarized in Table 1 have shown a substantial impact of the gamma radiation on crumb rubber properties and, by extension, on the modified bitumen or asphalt concrete rheological aspect. The modification of the crumb rubber's surface due to cross-linking and scission reaction positively impacts the material's mechanical properties. Viscosity and aging, also altered, proving the treatment's effectiveness while adding a considerable amount of irradiated rubber in the asphalt. The reduced need to control expositions' distance makes this method suitable for powder materials as for more oversized shape materials. 
Table 1. Summary of studies on the procedures and results using gamma ray treatment.

\begin{tabular}{|c|c|c|c|}
\hline Reference & Method/Procedures & Analysis & Results \\
\hline \multirow{4}{*}{ Faldini et al. [52] } & $\underline{\text { Rubber type: ELTs Rubber }}$ & SEM & $\begin{array}{l}\text { Increase of roughness with } \\
\text { irradiation. }\end{array}$ \\
\hline & $\underline{\text { Rubber size: }}(0.044-4.75 \mathrm{~mm})$ & & - $\quad$ Less porosity with $1000 \mathrm{kGy}$ \\
\hline & Dose rate: $11.6 \mathrm{kGy} / \mathrm{h}$ & FTIR & $\begin{array}{l}\text { - Absence of bulk degradation and } \\
\text { composition modification }\end{array}$ \\
\hline & $\begin{array}{l}\text { Doses: } 500 \& 1000 \mathrm{kGy} \\
\text { Institutional Reactor }\end{array}$ & $\begin{array}{l}\text { TGA } \\
\text { DSC }\end{array}$ & $\begin{array}{l}\text { - Insignificant change of } \\
\text { thermal decomposition }\end{array}$ \\
\hline \multirow{5}{*}{ Chen et al. [54] } & $\begin{array}{l}\text { Rubber type: Butyl rubber based } \\
\text { damping material (vulcanized) }\end{array}$ & Soxhlet extraction & $\begin{array}{l}\text { Small extractive increase with } \\
\text { absorbed does }\end{array}$ \\
\hline & $\underline{\text { Rubber size: Several }}$ & FTIR & $\begin{array}{l}\text { Increase of organic compound due } \\
\text { to the radiolysis and scission }\end{array}$ \\
\hline & Dose rate: $6.6 \mathrm{kGy} / \mathrm{h}$ & SEM & $\begin{array}{l}\text { Holes decrease and smoother } \\
\text { surface with the increase of doses }\end{array}$ \\
\hline & Doses: $10 ; 100 ; 200 ; 350$ kGy & Dynamic mechanical properties & $\begin{array}{l}\text { Elongation breaks increase with } \\
\text { irradiated dose }\end{array}$ \\
\hline & Institutional Reactor ${ }^{60} \mathrm{Co}$ & Tensile properties & $\begin{array}{l}\text { Tensile strength decreases with } \\
\text { dose increase }\end{array}$ \\
\hline \multirow{9}{*}{ Martínez-Barrera et al. [53] } & Rubber type: ELTs Rubber & SEM & $\begin{array}{l}\text { Increase of texturization with the } \\
\text { radiation dose }\end{array}$ \\
\hline & $\underline{\text { Rubber size: }} 0.85-2.8 \mathrm{~mm}$ & XRD & $\begin{array}{l}\text { Crystallinity maintained but } \\
\text { decreased with increasing dose. }\end{array}$ \\
\hline & Dose rate: $2.5 \mathrm{kGy} / \mathrm{h}$ & & - Maximum cross-link at $250 \mathrm{kGy}$ \\
\hline & Doses: 200; 250; 300 kGy & FTIR & $\begin{array}{l}\text { Increase of organic fractions due } \\
\text { to scission reactions. }\end{array}$ \\
\hline & Institutional Reactor ${ }^{60} \mathrm{Co}$ & Raman & - $\quad$ Chemical structure not changed \\
\hline & & UV-Visible & $\begin{array}{l}\text { Increase in reflectance with } \\
\text { the dose }\end{array}$ \\
\hline & & TGA & $\begin{array}{l}\text { The hardness of rubber increases } \\
\text { with the dose }\end{array}$ \\
\hline & & DSC & $\begin{array}{l}\text { Polymer more amorphous due to } \\
\text { cross-link reactions }\end{array}$ \\
\hline & $\begin{array}{l}\text { Inside of concrete } \\
1,2 \text { and } 5 \% \text { by weight }\end{array}$ & $\begin{array}{l}\text { Compressive strength and elasticity } \\
\text { modulus (ASTM C39/C39M-14) }\end{array}$ & $\begin{array}{l}\text { Increase of elasticity with higher } \\
\text { dose of irradiation }\end{array}$ \\
\hline \multirow{5}{*}{ Ibrahim et al. [23] } & $\begin{array}{l}\text { Rubber type: ELTs Rubber } \\
\text { Rubber size: } 2 \mathrm{~mm} \\
\text { Dose rate: } 2.8 \mathrm{kGy} / \mathrm{h}\end{array}$ & SEM & $\begin{array}{l}\text { Irregular domain size, small } \\
\text { roughness and decrease of holes }\end{array}$ \\
\hline & Doses: 100; 200; 300 kGy & FTIR & $\begin{array}{l}\text { Observation of carbon-oxygen } \\
\text { based groups due to scission }\end{array}$ \\
\hline & Institutional Reactor & Rheological & $\begin{array}{l}\text { Plastic viscosity decreases with } \\
\text { the increase of dose }\end{array}$ \\
\hline & Inside of asphalt & RTFOT & $\begin{array}{l}\text { - Low mass-loss and phase } \\
\text { separation with the increase } \\
\text { of dose }\end{array}$ \\
\hline & 5 and $10 \%$ weight & Anti-ageing & $\begin{array}{l}\text { Improvement in stability with the } \\
\text { increase of dose }\end{array}$ \\
\hline
\end{tabular}




\subsubsection{UV-Ozone Treatment}

Effect of UV radiation's action on dioxygen molecules $\left(\mathrm{O}_{2}\right)$, the ozone is a wellknown component to be in charge of surface sanitation of materials by using rubber-based products in the UV-Ozone generator (Figure $5 \mathrm{a}, \mathrm{b}$ ). Indeed, the ozone has an huge effect on the modification of carbon bonds by oxidation of the rubber [55] and is also used for largescale water purification (Figure 5c). An ozone-oxidation or ozonation reaction permits the creation of ozone-based layer formation that initiated the surface ablation yet an increase in texture of the material's layer [56].

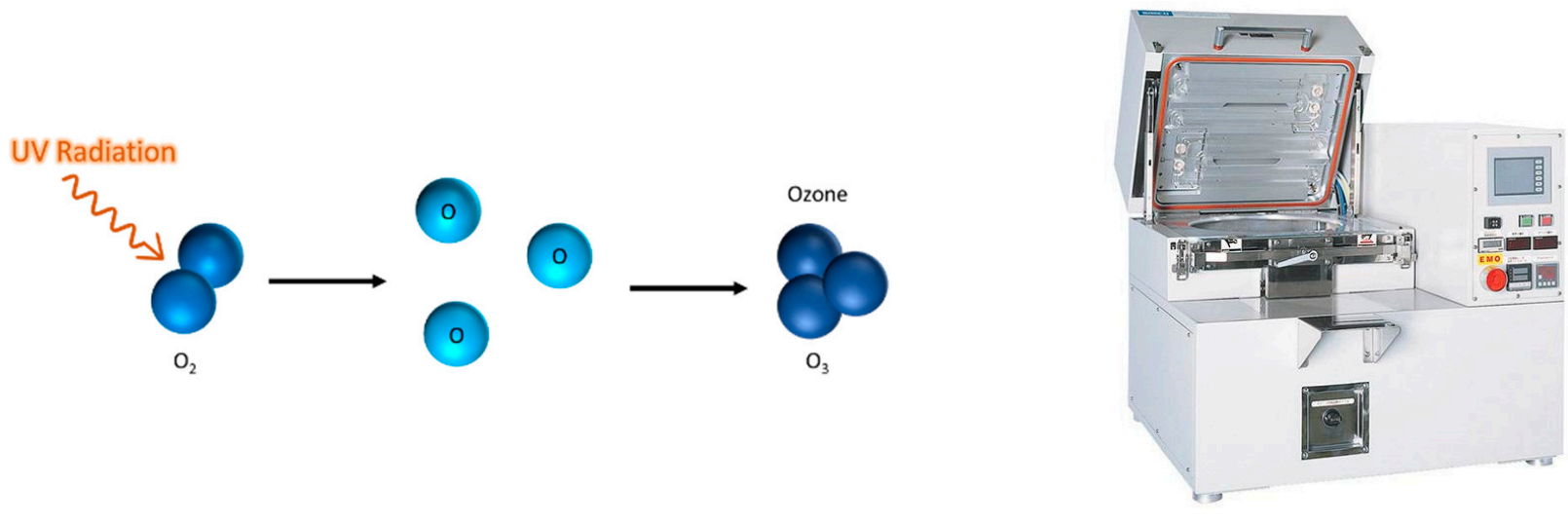

(a)

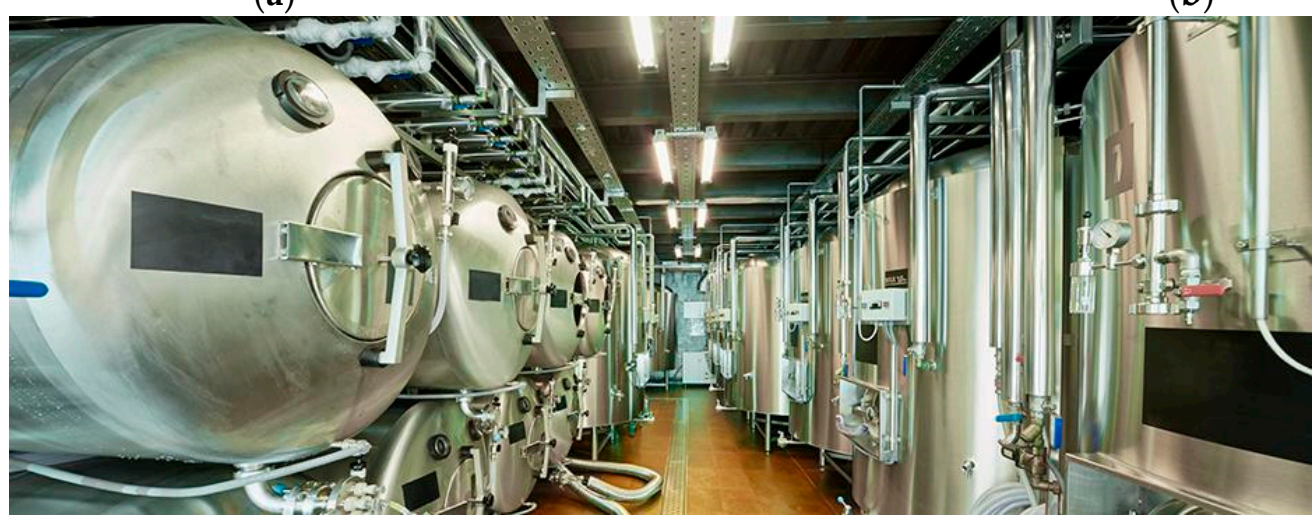

(c)

Figure 5. (a) Simplified scheme of the gamma ray initiation; (b) picture of a UV-Ozone instrument designed for lab work $\mathrm{SamCo}^{\mathrm{TM}}$; (c) picture of a brewing industry using UV-ozone treatment Mellifiq ${ }^{\mathrm{TM}}$.

Therefore, as for gamma radiation, UV radiation is a possible ionizing electromagnetic ray candidate for replacing polymers' chemical surface reaction and modification using solvent-based chlorination. Indeed, despite its proven effectiveness, chlorination of rubber requires long times of reaction and organic solvents. Furthermore, chlorine production, is environmentally dangerous and can cause potential health problems. A combination of UV radiation and ozone at different concentration has been proven to enhance the rubber surface's bonding performance, thus improving the vulcanized rubber's surface energy (Figure 6). The use of this physical treatment is considered to be cleaner and faster than others $[22,33,57]$. However, it has to be made in a very controlled condition in order to avoid the full degradation of the rubber. The exposition distance $[21,58,59]$ or the humidity $[56]$ are inevitably responsible for the degree of ozone-oxidation.

In the study of Moyano et al. [22], the treatment with UV-ozone increased the rubber's adhesion to polyurethane adhesive. The highest adhesion was obtained for the tests made with UV-ozone treated rubber for $3 \mathrm{~min}$ at a UV radiation source-surface distance of $5 \mathrm{~cm}$ with a limited concentration of ozone [22]. The reaction of ozone-oxidation allows to have 
cross-linking reaction causing an increase of the texture. The reaction is responsible (as for the gamma irradiation) for improving the CR's mechanical properties. However, more variables are concerned and must be controlled. Indeed, the distance of treatment along with time is an important factor. For instance, the effectiveness observed at $1 \mathrm{~cm}$ for $3 \mathrm{~min}$ treatment was less than the one observed at $5 \mathrm{~cm}$. A too close UV radiation or too long time can negatively affect the rubber.



Figure 6. Simplified scheme of the ozone reaction initiation and effect on rubber surface.

Iwase et al. [56] assessed the humidity's effect on the degradation of carbon black vulcanized rubber (very similar to tires rubber). The presence of constant ozone concentration has higher oxidative capabilities and is more aggressive without humidity. Under low humidity, the ozone leads to aggressive cross-linking reaction allowing deeper cracks while under high humidity, chain scission can also be observed. It leads to more shallow cracking of the layer and regular texturization as observed in Figure 7.

\section{Ozone at $80 \% \mathrm{RH}$}



Ozone at 20\% RH

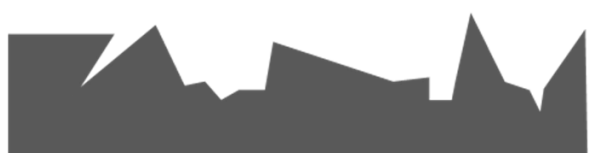

Figure 7. Simplified scheme of the ozone action under different humidity conditions [56].

Regardless of the application, UV-ozone treatment influences the surface behavior of rubber and other polymers. As summarized with the Table 2, the adhesion by the binder is the most wanted property, and this should have a potential effect even for the final rubberized asphalt or other binder applications. However, it has to be controlled to avoid deep degradation of the rubber and lead to a decrease of the elastic properties. The concentration of ozone, the distance of the UV radiation, and the humidity during the treatment must be controlled and can make this treatment less advantageous for treating large quantities of materials. 
Table 2. Summary of the studies on the procedures and results using UV-ozone treatment.

\begin{tabular}{|c|c|c|c|}
\hline Reference & Method/Procedures & Analysis & Results \\
\hline \multirow{5}{*}{ Moyano et al. [22] } & \multirow{5}{*}{$\begin{array}{l}\text { Rubber type: Vulcanized SBS rubber } \\
\text { UV lamp: } 254 \mathrm{~nm}(90 \%) \text { and } 185 \mathrm{~nm}(10 \%) \\
\text { Radiation intensity: } 10 \mathrm{~mW} / \mathrm{cm}^{2} \\
\text { Distance from lamp: } 1-5 \mathrm{~cm} \\
\text { Ozone concentration: Low } \\
\text { Humidity: Uncontrolled }\end{array}$} & ATR-IR & - $\quad$ Hydroxyl groups formation \\
\hline & & XPS & - Proof of oxidation group \\
\hline & & Contact angle & $\begin{array}{l}\text { - } \quad \text { Best at } 5 \mathrm{~cm} \text { for shorter time }(3 \mathrm{~min}) \\
\text { - } \quad \text { Less at } 1 \mathrm{~cm} \\
\end{array}$ \\
\hline & & SEM & $\begin{array}{l}\text { Production of ablation for the short } \\
\text { length of treatment, and roughness } \\
\text { and cracks are created for the long } \\
\text { length of treatment }\end{array}$ \\
\hline & & T-peel test & $\begin{array}{l}\text { Increase in adhesion with } \\
\text { polyurethane after treatment }\end{array}$ \\
\hline \multirow{2}{*}{ Iwase et al. [56] } & \multirow{2}{*}{$\begin{array}{l}\text { Rubber type: Vulcanized carbon } \\
\text { black-filled Rubber } \\
\text { Ozone concentration: High } \\
\text { Humidity and temperature: } \\
40^{\circ} \mathrm{C} 80 \% \mathrm{RH} \text { or } 80^{\circ} \mathrm{C} 20 \% \mathrm{RH}\end{array}$} & SEM & $\begin{array}{l}\text { - Shallow crack at high humidity, deep } \\
\text { cracks at low humidity }\end{array}$ \\
\hline & & ATR-IR & $\begin{array}{l}\text { - Hydroxyl group are formed due to } \\
\text { the oxidation }\end{array}$ \\
\hline
\end{tabular}

\subsubsection{Microwaves Irradiation}

Similarly to gamma and UV, the microwave radiation is electromagnetic and generally produced by a magnetron (Figure $8 \mathrm{a}$ ). However, the microwave frequency range is lower than gamma and UV (0.3-300 Ghz), making the microwave non-ionizing, less hazardous to humans, and widely used for telecommunications small or large microwave devices (Figure $8 b, c)$. The wavelength conducts to an energy photon unable to divide molecular bond and so induce chemical reactions by direct absorption of electromagnetic energy instead of ultraviolet. The microwave role is to accelerate and enhance the rate of a variety of chemical reactions happening slowly without microwave excitation. Indeed, the length of treatment can be lowered from hours to minutes [43,58,59].

It is known that microwaves increase the molecular vibrations and lower the energy needed for radical initiation or surface activation. Therefore, nowadays, microwaves irradiation is generally used to enhance polymerization in presence of radicals [60] that can create small fragmentation and reticulations or permit to devulcanize the network created by the bonding (Figure 9) due to the addition and reaction with sulfur and, subsequently, improve rubber's viscoelastic nature $[15,16,18,58]$.

This method effectively makes the vulcanized rubber more viscoelastic and easier to recover, but it can damage the material's whole structure by breaking surface sulfur links or creating other uncontrolled bonds if using aggressive power for instance. Thus, the process needs to be correctly monitored to avoid the degradation of the leading chains. The exposure to the microwave radiation and the rubber's temperature at the end of the reaction needs to be defined not to degrade the rubber structurally. Indeed, the higher is the exposition to the microwaves, the higher is the temperature at the end of the reaction, hence the higher will be the devulcanization. When the aim is to modify the surface, the exposure should not last longer ( 1 to $5 \mathrm{~min}$ ) and be too aggressive (up to 800 Watts) [14,17]. The radiation can also be combined with activators to enhance the rubber materials' irradiation's desired effect [16]. The combination of both microwave (400 watts) and soft biochemical modification improves the modification level.

Yang et al. [61] have proposed a reaction mechanism with or without CR treatment with microwave for $90 \mathrm{~s}$ at $800 \mathrm{~W}$. The cross-linking reaction causing cracks on the surface enhance the stability of the rubber inside of the mix and reduce the phase segregation created by the usual swelling of untreated particles as illustrated in Figure 10. The microwaves also show positive behavior regarding the high-temperature performances and the release of volatile gases after DSR and FT-IR analysis. 




(a)

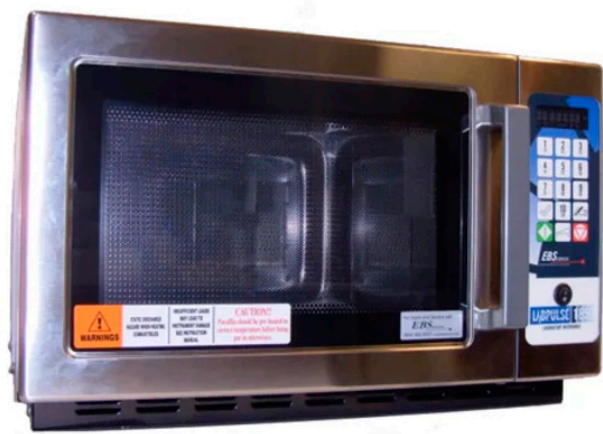

(b)

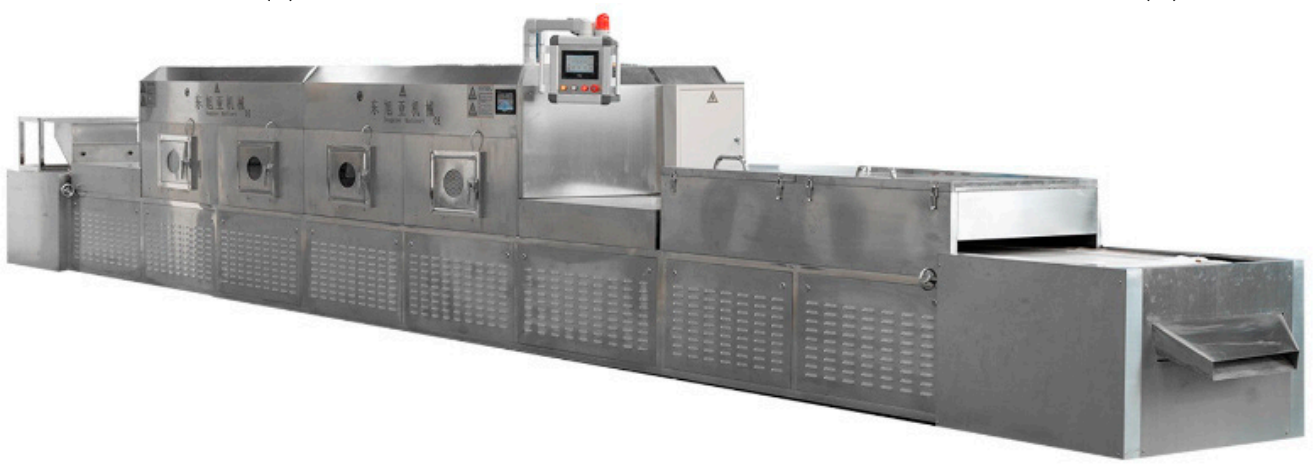

(c)

Figure 8. (a) Simplified scheme of the microwaves formation by magnetron; (b) picture of a microwave instrument designed for lab work Labpulse ${ }^{\circledR}$; (c) picture of Large-scale microwave chain Xujia ${ }^{\mathrm{TM}}$.

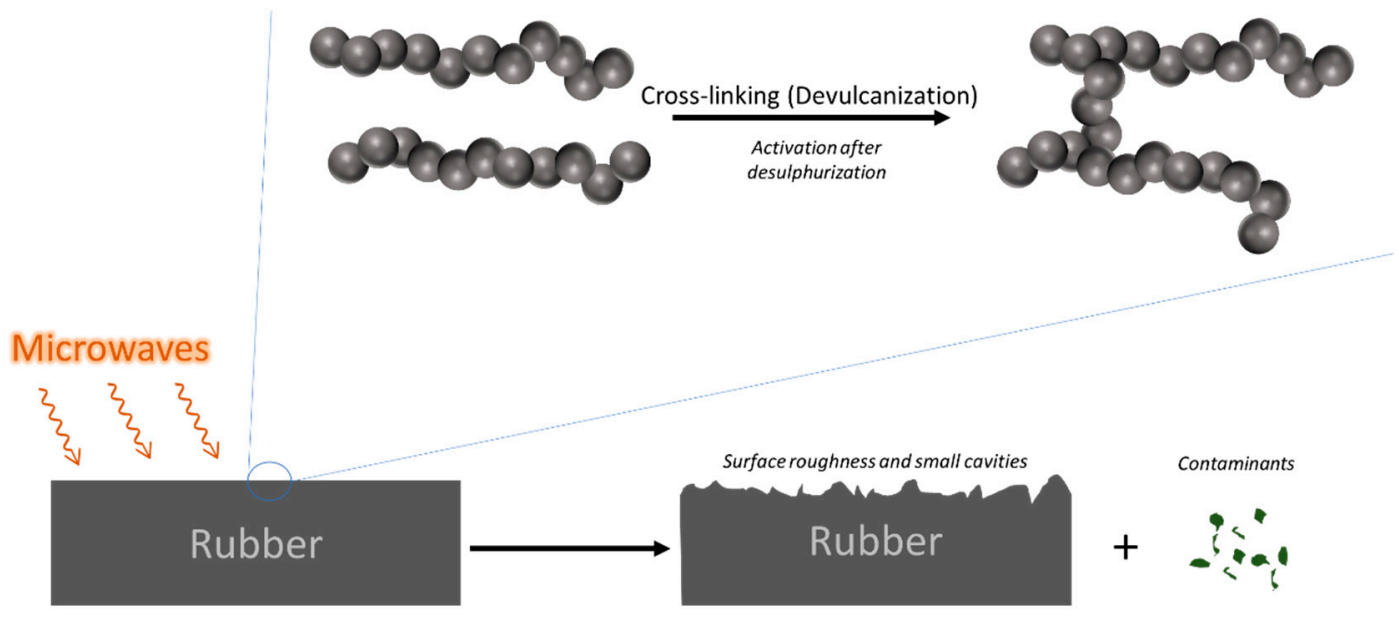

Figure 9. Simplified scheme of the microwaves effect on rubber surface.

On the other hand, the study made by Liang et al. [62] proved the effectiveness of a microwave treatment to enhance surface modification and permit the rubber to resist thermal cracking due to high temperature drop [62]. However, the defined procedure can give negative results regarding the stability of the mix with asphalt if the reaction enhanced by the microwaves is too aggressive. The microwave has to be severely controlled to not undergo a negative behavior regarding the asphalt binder because it can increase the surface porosity. 




Figure 10. Proposed mechanism while incorporating microwaves-treated or untreated rubber [61].

The microwave action is already well-known for rubber devulcanization, but also shows the specific action on the rubber, when mixing with the asphalt binder. Indeed, as shown in Table 3, the treatment can minimize the swelling, improve the mix's stability, and reduce the release of volatile gas when mixing it with the binder [61]. As the microwave process needs little time and, because the aim is not to modify the rubber's whole structure, the use of this method can be successfully transposed to the mass-treatment approach and thus applied while mixing asphalt binder and CR.

Table 3. Summary of studies on the procedures and results using microwaves treatment.

\begin{tabular}{|c|c|c|c|}
\hline Reference & Method/Procedures & Analysis & Results \\
\hline \multirow[b]{2}{*}{ De Sousa et al. [16] } & \multirow{2}{*}{$\begin{array}{l}\text { Rubber type: ELTs crumb rubber } \\
\text { Rubber size: } 0.177 \mathrm{~mm} \\
\text { Power: } 800 \text { watts } \\
\text { Treatment length: } 1,5 \text {, and } 5.5 \mathrm{~min}\end{array}$} & ATR-FTIR & - $\quad$ Long exposure new liaison Sulphur \\
\hline & & Sol-Gel content & $\begin{array}{l}\text { Increase of devulcanization during } \\
\text { the time decrease of gel fraction } \\
\text { with time }\end{array}$ \\
\hline \multirow{6}{*}{ Yang et al. [61] } & \multirow{6}{*}{$\begin{array}{l}\text { Rubber type: ELTs crumb rubber } \\
\text { Rubber size: } 0.35 \mathrm{~mm} \\
\text { Power: } 800 \text { watts } \\
\text { Treatment length: } 1.5 \mathrm{~min} \\
\text { Inside of asphalt binder } \\
\text { 10,15, } 20 \% \text { rubber weight }\end{array}$} & SEM & - Increase of surface texture \\
\hline & & DSR & $\begin{array}{l}\text { - } \quad \text { Microwaves improve high } \\
\text { temperature performance. }\end{array}$ \\
\hline & & GPC & $\begin{array}{l}\text { More swelling reaction of the } \\
\text { without microwave pre-treatment }\end{array}$ \\
\hline & & AFM & $\begin{array}{l}\text { More uniform structure with } \\
\text { pre-treated rubber }\end{array}$ \\
\hline & & FT-IR & $\begin{array}{l}\text { High powered microwave has more } \\
\text { effect on cross-linked } \\
\text { sulfide bond in rubber } \\
\text { - } \quad \text { Less volatile gas when } \\
\text { microwave activated }\end{array}$ \\
\hline & & TGA & $\begin{array}{l}\text { Decomposition temperature } \\
\text { decreased with microwaves }\end{array}$ \\
\hline
\end{tabular}


Table 3. Cont.

\begin{tabular}{|c|c|c|c|}
\hline Reference & Method/Procedures & Analysis & Results \\
\hline \multirow{5}{*}{ Liang et al. [62] } & \multirow{5}{*}{$\begin{array}{l}\text { Rubber type: Cryogenic ELTs crumb rubber } \\
\text { Rubber size: } 0.420 \mathrm{~mm} \\
\text { Power: } 500 \text { watts } \\
\text { Treatment length: } 5 \mathrm{~min} \\
\text { Inside of asphalt binder } \\
4.5 \% \text { rubber weight }\end{array}$} & FT-IR & - $\quad$ Cross-linking reaction happening \\
\hline & & SEM & - Increase of texture \\
\hline & & Low temperature creep behavior & Better with microwave treatment \\
\hline & & $\begin{array}{l}\text { Viscoelastic performance } \\
\text { intermediate temperatures }\end{array}$ & - Degraded with microwave treatment \\
\hline & & Storage stability & better with microwave treatment \\
\hline
\end{tabular}

\subsubsection{Plasma Treatment}

Plasma is the fourth state of matter considered after solid, liquid, and gas, resulting in a gas ionization (Figure 11a). It has been used in lab (Figure 11b) and large-scale polymer materials coating and functionalization in diverse fields as textiles, medicine, hazardous waste handling, or electronics in the last 60 years as shown in Figure 11c [57,63].

Most of these applications involve the use of low pressure and low-temperature plasma. Its treatment has several significant benefits compared to traditional wet chemistry techniques. The plasma treatment modifies only the top 0.01 microns of the material layer and permits faster reaction on the surface owing to the free ions and electron and the beam's high energy. Thus, various materials' desired surface properties, including rubber-based, are achieved without altering their bulk material characteristics. Plasma has been found to improve rubbers' adhesion owing to an increase in surface roughness caused by the formation of polar moieties on the surface and ablation of low molecular weight compounds (Figure 12), hence cleaning the surface [33,64].
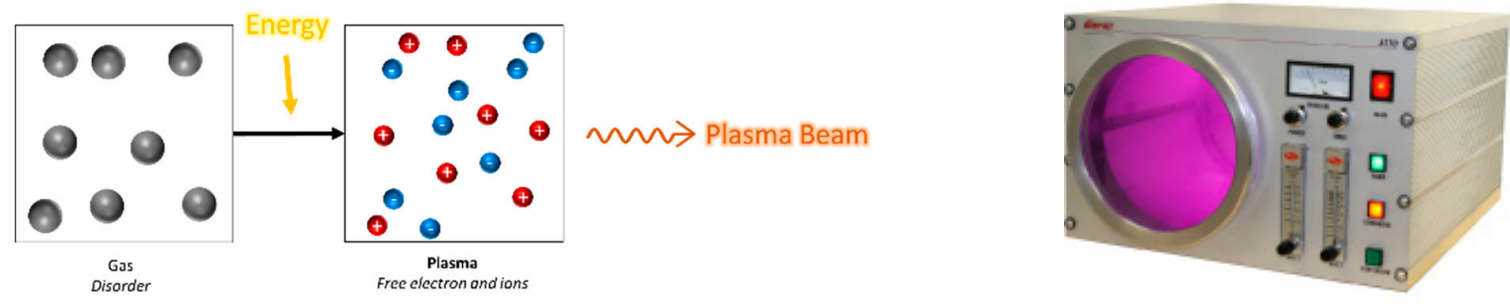

(a)

(b)

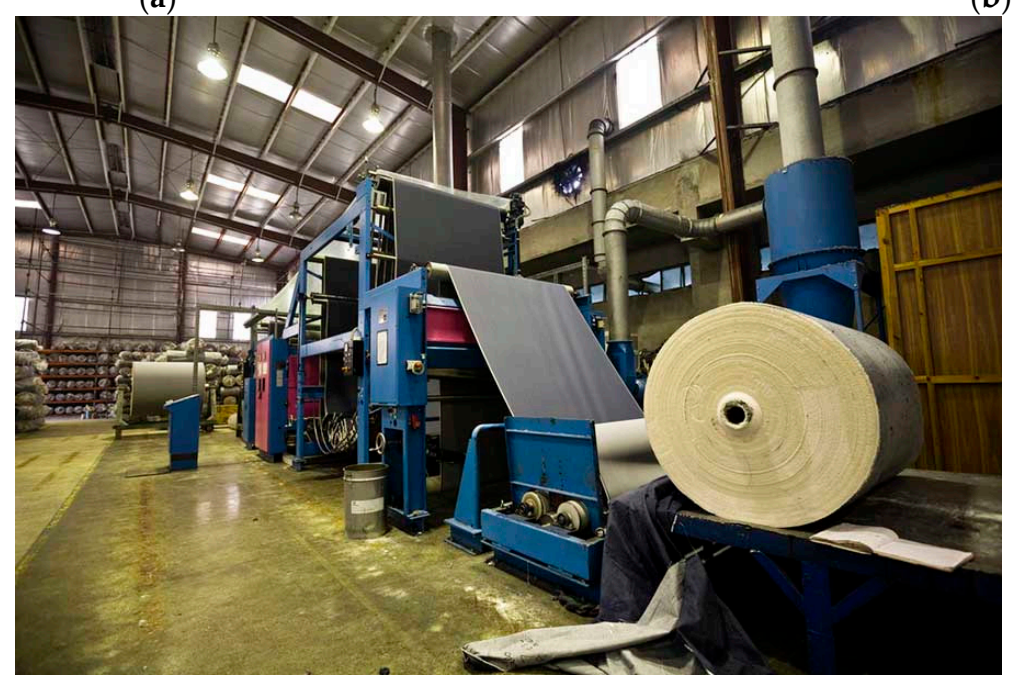

(c)

Figure 11. (a) Simplified scheme of the plasma formation; (b) picture of a plasma generator designed for lab work Rotalab ${ }^{\mathrm{TM}}$; (c) picture of a large-scale plasma treatment chain Henniker ${ }^{\mathrm{TM}}$. 


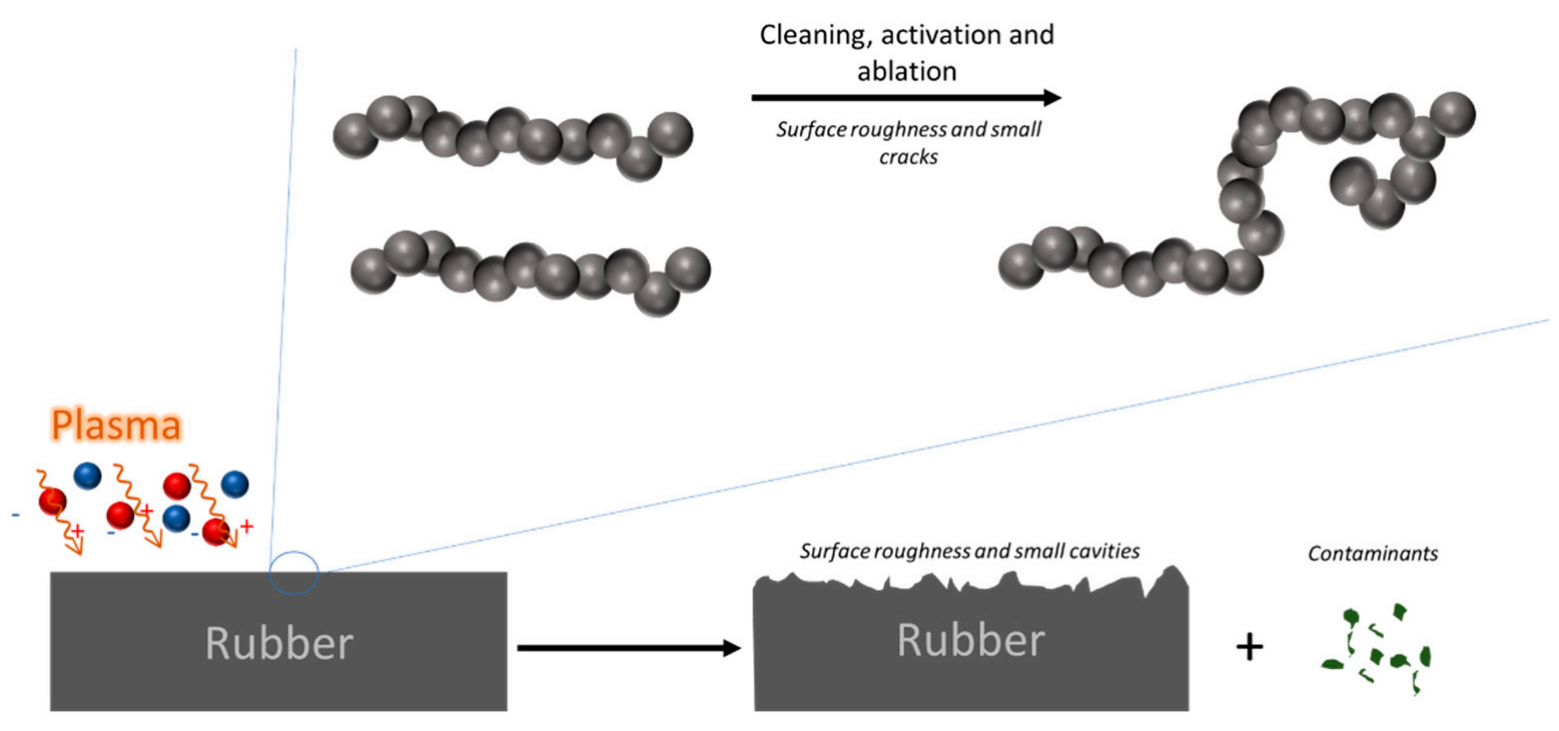

Figure 12. Simplified scheme of plasma effect on rubber surface.

In a research by Ortiz-Magan et al. [65], both nitrogen $\mathrm{N}_{2}$ and oxygen $\mathrm{O}_{2}$ plasma treatment were used to improve rubber adhesion to another polymer (polyurethane), generally used for playgrounds or in the shoes industry together with the crumb rubber. The reaction was conducted for 1-15 min using a $50 \mathrm{~W}$ power reactor. In general, zinc and oil on rubber, due to the vulcanization, create an anti-adherent layer on the surface, decreasing the interaction between the rubber and the studied adhesive. In this specific study, the more noticeable effect was the grafting of oxygen and enhancing rubber's surface texture owing to $\mathrm{O}_{2}$ plasma [65]. The wettability was considerably improved owing to removing the sulfur layer from the surface and creating $\mathrm{C}=\mathrm{O}$ surface bonds. This sulfur layer reduction is also an actor in the enhancement of the viscosity of the rubber.

Similar results were observed in the study made by Xiaowei et al. [66] by using $\mathrm{O}_{2}$ plasma. Even if the final aim was to initiate another polymerization after pre-treatment of rubber by plasma, the rubber has precisely the same behavior. The plasma causes ablation to clean the surface and make it more reactive.

Li et al. [67] discussed the use of cold plasma (air)-treated powder rubber $((0.177 \mathrm{~mm}$, $0.420,0.595 \mathrm{~mm}$ ) inside of a binder. After incorporating $15 \%$ weight of treated and untreated rubber, the plasma treatment has shown improvement in the high temperature performances, the thermal storage stability of the asphalt binder by improving the rubber's contact reactivity.

The studies summarized in Table 4 show that, $\mathrm{O}_{2}$ and cold (air) plasma treatment can represent a solution for using crumb rubber inside of asphalt mixes regarding the stability and compatibility properties. Methods exist for the treatment of powders, however it causes difficulty in the treatment for large-scale processing. While treated with plasma, the rubber can directly be incorporated inside of an asphalt binder (wet) fostering the link possibilities between the binder and the rubber. This effect can be enhanced while using emulsion type of binder owing to the rubber surface's wettability.

\subsubsection{Advantages and Disadvantages of the Main Solution for an Application to Highly} Rubberized Road Pavements

Each treatment solutions presented have a crucial effect on the rubber surface modification. However, several limitations arise while mentioning the use of a considerable amount of rubber for the construction of road surface layers. Table 5 compares the characteristics of the main proposed solutions. 
Table 4. Summary of studies on the procedures and results using plasma treatment.

\begin{tabular}{|c|c|c|c|}
\hline References & Method/Procedures & Standard for Assessment & Results \\
\hline \multirow{7}{*}{ Ortiz-Magan et al. [65] } & \multirow{7}{*}{$\begin{array}{l}\text { Rubber type: Volcanized SBS } \\
\text { rubber } \\
\text { Type of plasma: Low-Pressure } \mathrm{N}_{2} \\
\text { and } \mathrm{O}_{2} \\
\text { Power: } 50 \mathrm{~W} \\
\text { Treatment length: } 1 \text { to } 15 \mathrm{~min} \\
\text { Lab plasma chamber }\end{array}$} & ATR-IR & $\begin{array}{l}\text { Modification of the } \\
\text { surface chemistry }\end{array}$ \\
\hline & & & $\begin{array}{l}\text { Formation of Si-O group } \\
\text { due to removal of } \\
\text { sulfur liaison } \\
\text { - } \quad \begin{array}{l}\text { Hydrocarbon group due to } \\
\text { oxidation. More polar group } \\
\text { on the surface }\end{array}\end{array}$ \\
\hline & & XPS & $\begin{array}{l}\text { Hydrocarbon-rich rubber } \\
\text { surface. Oxidation of } \\
\text { the surface }\end{array}$ \\
\hline & & SFM & $\begin{array}{l}\text { Texturization increase with } \\
\text { time treatment }\end{array}$ \\
\hline & & SEM & $\begin{array}{l}\text { - } \mathrm{O}_{2} \text { decrease of porosity } \\
\text { increase of texturization }\end{array}$ \\
\hline & & Contact angle & $\begin{array}{l}\text { Decrease of contact angle } \\
\text { with water and ethane diol } \\
\text { after } 1 \text { minute treatment } \\
\text { High wettability with } \\
\text { ethane diol after } \mathrm{N}_{2} \\
\text { plasma treatment }\end{array}$ \\
\hline & & T-peel & $\begin{array}{l}\text { - Adhesion improved with } \\
\mathrm{O}_{2} \text {. Need extended } \\
\text { treatment with } \mathrm{N}_{2}\end{array}$ \\
\hline \multirow{4}{*}{ Xiaowei et al. [66] } & \multirow{4}{*}{$\begin{array}{l}\text { Rubber type: Crumb rubber } \\
\text { Pressure: } 10 \mathrm{~Pa} \\
\text { Plasma type: } \mathrm{O}_{2} \text { plasma } \\
\text { Power: } 60,80,100,120 \mathrm{~W} \\
\text { Treatment length: } 1 \text { to } 5 \mathrm{~min} \\
\text { Lab plasma chamber }\end{array}$} & ATR-IR & $\begin{array}{l}\text { Modification of the } \\
\text { surface chemistry }\end{array}$ \\
\hline & & Contact angle & $\begin{array}{l}\text { Formation of Si-O group } \\
\text { due to removal of } \\
\text { Sulphur liaison } \\
\text { More polar group on } \\
\text { the surface }\end{array}$ \\
\hline & & SEM & - Increase of texture \\
\hline & & XPS & $\begin{array}{l}\text { - Oxygen group } \\
\text { content increase }\end{array}$ \\
\hline \multirow[t]{2}{*}{ Li et al. [67] } & $\begin{array}{l}\text { Rubber type: ELTs crumb rubber } \\
\text { Size of particles: }(0.177 \mathrm{~mm}, 0.420 \text {, } \\
0.595 \mathrm{~mm}) \\
\text { Plasma Type: Air plasma } \\
\text { Power: } 250 \mathrm{~W} \\
\text { Treatment length: } 8 \mathrm{~min} \\
\text { Lab plasma chamber }\end{array}$ & SEM & $\begin{array}{l}\text { - Surface roughness } \\
\text { enhancement, surface } \\
\text { contamination removal }\end{array}$ \\
\hline & $\begin{array}{l}\text { Inside of the binder } \\
2 \text { Type of binder } \\
15 \% \text { weight rubber }\end{array}$ & $\begin{array}{l}\text { High-temperature properties } \\
\text { (rotational viscosity, failure } \\
\text { temperature, rutting factor, phase } \\
\text { angle, storage modulus, loss modulus) }\end{array}$ & $\begin{array}{l}\text { Enhancement of } \\
\text { high-temperature properties } \\
\text { Better thermal storage of } \\
\text { modified binder }\end{array}$ \\
\hline
\end{tabular}

Highly referenced, the gamma-ray enables the increase of the rubber surface's roughness without modifying its high elastic properties, and the gain in mix stability while mixed with asphalt binder. However, this radiation remains radioactive and highly penetrating, 
thus requiring high surveillance while treating the materials either during lab or industrial treatment. Also, to obtain the described results, the length of treatment is considered to last hours.

Despite its well-known cleaning effect on the surface of the treated materials improving adhesive properties and its rapidity, the UV-ozone treatment is challenging to apply because of the considerable number of parameters to control (ozone concentration, humidity, distance of exposition). Besides, the treatment on fine rubber powders can be troublesome.

The microwave treatment proved its efficacity in controlling rubber's swelling reaction in contact with asphalt binder. Besides, owing to its effect on the rubber causing specific surface parameters, the use of microwaved rubber can reduce the release of volatile and hazardous gases. However, the length and power of radiation must be short and controlled to avoid a full devulcanization or parasite polymerizations.

The plasma has been presented as the fastest method permitting effective results after a few seconds of treatment. Furthermore, owing to the decrease of surface contaminant and rubber texture, the treatment enhances the high-temperature and thermal storage while mixed with the asphalt binders.

For the dry and wet processes, the microwaves and plasma treatments appear to correspond with the usual procedure, potential hazardousness, length treatment, and results obtained while mixing with asphalt binder. The ease in acquiring a microwave generator compared to a plasma chamber makes microwave treatment easier to replicate also in lab conditions.

Table 5. Comparison between main physical surface treatment solutions.

\begin{tabular}{|c|c|c|c|c|c|}
\hline Methods & $\begin{array}{l}\text { Major Effect } \\
\text { on the Surface }\end{array}$ & Radiation Type & Treatment Length & $\begin{array}{c}\text { Parameters } \\
\text { Control }\end{array}$ & Applicability \\
\hline Gamma & $\begin{array}{l}\text { Softening } \\
\text { Texturization }\end{array}$ & $\begin{array}{c}\text { Radioactive } \\
\text { highly-penetrating and } \\
\text { ionizing }\end{array}$ & hours & $\begin{array}{l}\text { Control of the } \\
\text { absorbed dose and } \\
\text { length of treatment }\end{array}$ & $\begin{array}{l}\text { Applicable to several } \\
\text { shapes of material } \\
\text { Difficult to acquire a } \\
\text { gamma ray equipment. }\end{array}$ \\
\hline UV-Ozone & $\begin{array}{c}\text { Ablation } \\
\text { Softening } \\
\text { Texturization }\end{array}$ & $\begin{array}{l}\text { Penetrating and } \\
\text { ionizing }\end{array}$ & hours & $\begin{array}{l}\text { Control of radiation } \\
\text { distance, ozone } \\
\text { concentration, and } \\
\text { humidity values. }\end{array}$ & $\begin{array}{l}\text { Applicable to several } \\
\text { shapes of materials but } \\
\text { challenging with } \\
\text { powders. } \\
\text { Several existing } \\
\text { apparatuses }\end{array}$ \\
\hline Microwaves & $\begin{array}{c}\text { Reactions' } \\
\text { acceleration } \\
\text { Desulfurization } \\
\text { Softening }\end{array}$ & Non-penetrating & minutes & $\begin{array}{l}\text { Control of the length } \\
\text { of treatment and } \\
\text { power }\end{array}$ & $\begin{array}{l}\text { Applicable to several } \\
\text { shapes of material } \\
\text { Easy to acquire a } \\
\text { microwave equipment. }\end{array}$ \\
\hline Plasma & $\begin{array}{l}\text { Activation } \\
\text { Ablation } \\
\text { Texturization }\end{array}$ & Non penetrating & seconds & $\begin{array}{c}\text { Control of the source } \\
\text { of plasma and length } \\
\text { of treatment }\end{array}$ & $\begin{array}{l}\text { Applicable to several } \\
\text { shapes of materials but } \\
\text { challenging with } \\
\text { powders. } \\
\text { Several existing } \\
\text { apparatus }\end{array}$ \\
\hline
\end{tabular}

\section{Conclusions}

This review focuses on using physical surface treatment to modify the rubber surface characteristics for the use of abundant CR generated from ELTs in pavement engineering applications.

The standard trend in all the presented methods is the gain of time during the functionalization reaction. These methods need a limited amount of time to produce a positive effect in terms of rubber surface modification.

The presented methods have also in common the structural modification of the surface. Either a specific characteristic can be created on the surface and other can be removed from the surface. Surface texturization can lead to better-mixing properties and affinity with 
the constituent, in particular the bituminous-based ones. Creating a more textured surface on top of the rubber is essential when mixing it with an asphalt binder to improve their bonding. The surface texturization results allow to modify the surface energy and it is also likely to enhance the adhesion properties, thus reducing the phase separation.

For asphalt applications, especially when incorporating a subsequent rubber quantity, the priority should be given to fast treatments. A dry and chemicals-free process permits the non-alteration of the rubber's bulk structure and limits the hazardous possibilities of the rubber modification process.

For either the dry or wet processes, all the mentioned solutions give desirable properties to the rubber for their use inside of bituminous materials. Nevertheless, the microwaves and plasma treatments appear to give better results with regard to the application in usual procedures, potential hazardousness and length treatment mostly. For instance, these treatments allowed the collection of better ageing, high temperatures performances or the reduction of volatile gasses when mixed in asphalt or bituminous mixtures. However, time and power of exposure to the different treatments as keys parameters to control should be mastered to avoid any reverse effects on the properties, when mixing the rubber with the asphalt binder.

The highest percentage of $\mathrm{CR}$ is targeted to study the suitability of its use in soft surfaces applications such as sports pitches and advanced impact-absorbing pavements for urban surfaces. Finally, other methods using chemical additives also exist (use of rejuvenators, waxes, chemicals, etc.), however, when using a recycled material, an ecocompatible treatment should be mainly addressed to expand the possible reclaiming lifetime of $C R$ and rubberized asphalt.

Author Contributions: Writing—original draft preparation, C.M.; writing—review and editing, C.M., K.J., V.W., C.S. All authors have read and agreed to the published version of the manuscript.

Funding: This research was funded by the European Union's Horizon 2020 research and innovation program under the Marie Skłodowska-Curie grant agreement N 765057 through SAFERUP! Project.

Acknowledgments: The acknowledgements gratefully go to the recycled crumb rubber and bitumen suppliers used during this project, all researchers related to this study in Italy, Sweden or generally in Europe. To the University of Bologna, Research Institutes of Sweden, Svensk Däckåtervinning AB and the SAFERUP! Consortium.

Conflicts of Interest: The funders had no role in the design of the study; in the collection, analyses, or interpretation of data; in the writing of the manuscript, or in the decision to publish the results.

\section{References}

1. Ateeq, M.; Al-Shamma'a, A. Experimental Study on the Optimisation of Chemical Treatment to Reduce Waste Rubber Aggregates Absorption Properties. Constr. Build. Mater. 2016, 126, 274-285. [CrossRef]

2. Kashani, A.; Ngo, T.D.; Hemachandra, P.; Hajimohammadi, A. Effects of Surface Treatments of Recycled Tyre Crumb on Cement-Rubber Bonding in Concrete Composite Foam. Constr. Build. Mater. 2018, 171, 467-473. [CrossRef]

3. Abdul Hassan, N.; Airey, G.D.; Putra Jaya, R.; Mashros, N.; Aziz, M.A. A Review of Crumb Rubber Modification in Dry Mixed Rubberised Asphalt Mixtures. J. Teknol. 2014, 70. [CrossRef]

4. Sangiorgi, C.; Eskandarsefat, S.; Tataranni, P.; Simone, A.; Vignali, V.; Lantieri, C.; Dondi, G. A Complete Laboratory Assessment of Crumb Rubber Porous Asphalt. Constr. Build. Mater. 2017, 132, 500-507. [CrossRef]

5. Eskandarsefat, S.; Sangiorgi, C.; Dondi, G.; Lamperti, R. Recycling Asphalt Pavement and Tire Rubber: A Full Laboratory and Field Scale Study. Constr. Build. Mater. 2018, 176, 283-294. [CrossRef]

6. Aliabdo, A.A.; Abd Elmoaty, A.E.M.; AbdElbaset, M.M. Utilization of Waste Rubber in Non-Structural Applications. Constr. Build. Mater. 2015, 91, 195-207. [CrossRef]

7. Mikhailenko, P.; Piao, Z.; Kakar, M.R.; Bueno, M.; Athari, S.; Pieren, R.; Heutschi, K.; Poulikakos, L. Low-Noise Pavement Technologies and Evaluation Techniques: A Literature Review. Int. J. Pavement Eng. 2020, 0, 1-24. [CrossRef]

8. Fédération Internationale de Football Association (FIFA). Quality Programme for Football Turf Handbook of Test Methods; FIFA: Zurich, Switzerland, 2015.

9. Ragn-Sells Däckåtervinning AB. "Rubber Granulate"; Ragn-Sells Däckåtervinning AB: Landskrona, Sweden, 2017.

10. Dondi, G.; Tataranni, P.; Pettinari, M.; Sangiorgi, C.; Simone, A.; Vignali, V. Crumb Rubber in Cold Recycled Bituminous Mixes: Comparison between Traditional Crumb Rubber and Cryogenic Crumb Rubber. Constr. Build. Mater. 2014, 68, 370-375. [CrossRef] 
11. Pettinari, M.; Dondi, G.; Sangiorgi, C.; Hededal, O. The Effect of Cryogenic Crumb Rubber in Cold Recycled Mixes for Road Pavements. Constr. Build. Mater. 2014, 63, 249-256. [CrossRef]

12. Dong, D.; Huang, X.; Li, X.; Zhang, L. Swelling Process of Rubber in Asphalt and Its Effect on the Structure and Properties of Rubber and Asphalt. Constr. Build. Mater. 2012, 29, 316-322. [CrossRef]

13. Daly, W.H.; Balamurugan, S.S.; Negulescu, I.; Akentuna, M.; Mohammad, L.; Cooper, S.B.; Cooper, S.B.; Baumgardner, G.L. Characterization of Crumb Rubber Modifiers after Dispersion in Asphalt Binders. Energy Fuels 2019, 33, 2665-2679. [CrossRef]

14. Lamperti, R.; Grenfell, J.; Sangiorgi, C.; Lantieri, C.; Airey, G.D. Influence of Waxes on Adhesion Properties of Bituminous Binders. Constr. Build. Mater. 2015, 76, 404-412. [CrossRef]

15. Bockstal, L.; Berchem, T.; Schmetz, Q.; Richel, A. Devulcanisation and Reclaiming of Tires and Rubber by Physical and Chemical Processes: A Review. J. Clean. Prod. 2019, 236, 117574. [CrossRef]

16. De Sousa, F.D.B.; Scuracchio, C.H.; Hu, G.-H.; Hoppe, S. Devulcanization of Waste Tire Rubber by Microwaves. Polym. Degrad. Stab. 2017, 138, 169-181. [CrossRef]

17. Seghar, S.; Asaro, L.; Rolland-Monnet, M.; Aït Hocine, N. Thermo-Mechanical Devulcanization and Recycling of Rubber Industry Waste. Resour. Conserv. Recycl. 2019, 144, 180-186. [CrossRef]

18. Asaro, L.; Gratton, M.; Seghar, S.; Aït Hocine, N. Recycling of Rubber Wastes by Devulcanization. Resour. Conserv. Recycl. 2018, 133, 250-262. [CrossRef]

19. Hosseinnezhad, S.; Kabir, S.F.; Oldham, D.; Mousavi, M.; Fini, E.H. Surface Functionalization of Rubber Particles to Reduce Phase Separation in Rubberized Asphalt for Sustainable Construction. J. Clean. Prod. 2019, 225, 82-89. [CrossRef]

20. Mousavi, M.; Hosseinnezhad, S.; Kabir, S.F.; Burnett, D.J.; Fini, E.H. Reaction Pathways for Surface Activated Rubber Particles. Resour. Conserv. Recycl. 2019, 149, 292-300. [CrossRef]

21. Han, L.; Zheng, M.; Li, J.; Li, Y.; Zhu, Y.; Ma, Q. Effect of Nano Silica and Pretreated Rubber on the Properties of Terminal Blend Crumb Rubber Modified Asphalt. Constr. Build. Mater. 2017, 157, 277-291. [CrossRef]

22. Moyano, M.A.; Martín-Martínez, J.M. Surface Treatment with UV-Ozone to Improve Adhesion of Vulcanized Rubber Formulated with an Excess of Processing Oil. Int. J. Adhes. Adhes. 2014, 55, 106-113. [CrossRef]

23. Ibrahim, I.M.; Fathy, E.S.; El-Shafie, M.; Elnaggar, M.Y. Impact of Incorporated Gamma Irradiated Crumb Rubber on the Short-Term Aging Resistance and Rheological Properties of Asphalt Binder. Constr. Build. Mater. 2015, 81, 42-46. [CrossRef]

24. Aderfors, F.; Roupé, J. The Road towards Sustainability in the Swedish Tyre Industry Association; Svensk Däckåtervinning AB: Vaxholm, Sweden, 2019.

25. Circular Economy. Available online: https://www.etrma.org/key-topics/circular-economy/ (accessed on 30 December 2020).

26. Bontoux, L.; Leone, F.; Nicolai, M.; Papameletiou, D. The Recycling Industry in the European Union: Impediments and Prospects; Institute for Prospective Technological Studies; European Commission-Joint Research Centre Institute for Prospective Technological Studies: Sevilla, Spain, 1996; p. 59.

27. European Tyres Rubber Manufactures Association. European Tyre and Rubber Industry-Statistics; ETRMA: Saint-Josse-ten-Noode, Belgium, 2019; p. 52.

28. Zanetti, M.C.; Fiore, S.; Ruffino, B.; Santagata, E.; Dalmazzo, D.; Lanotte, M. Characterization of Crumb Rubber from End-of-Life Tyres for Paving Applications. Waste Manag. 2015, 45, 161-170. [CrossRef]

29. Re Depaolini, A.; Bianchi, G.; Fornai, D.; Cardelli, A.; Badalassi, M.; Cardelli, C.; Davoli, E. Physical and Chemical Characterization of Representative Samples of Recycled Rubber from End-of-Life Tires. Chemosphere 2017, 184, 1320-1326. [CrossRef]

30. Li, P.; Ding, Z.; Zou, P.; Sun, A. Analysis of Physico-Chemical Properties for Crumb Rubber in Process of Asphalt Modification. Constr. Build. Mater. 2017, 138, 418-426. [CrossRef]

31. Piao, Z.; Mikhailenko, P.; Kakar, M.R.; Bueno, M.; Hellweg, S.; Poulikakos, L.D. Urban Mining for Asphalt Pavements: A Review. J. Clean. Prod. 2021, 280, 124916. [CrossRef]

32. Park, J.; Ju, W.; Paek, K.; Kim, Y.; Choi, Y.; Kim, J.; Hwang, Y. Pre-Treatments of Polymers by Atmospheric Pressure Ejected Plasma for Adhesion Improvement. Surf. Coat. Technol. 2003, 174-175, 547-552. [CrossRef]

33. Johansson, K.S. 20-Surface Modification of Plastics. In Applied Plastics Engineering Handbook (Second Edition); Plastics Design Library; Kutz, M., Ed.; William Andrew Publishing: Oxford, UK, 2017; pp. 443-487. ISBN 978-0-323-39040-8.

34. Purbrick, M.D. Polymer Surfaces: From Physics to Technology, Revised and Updated Edition I Wiley; John Wiley and Sons Ltd.: Chichester, UK, 2000; ISBN 0-471-97100-6.

35. Types of Radioactivity: Alpha, Beta, and Gamma Decay. Available online: https://chem.libretexts.org/Courses/can/intro/17\%3 A_Radioactivity_and_Nuclear_Chemistry/17.03\%3A_Types_of_Radioactivity\%3A_Alpha\%2C_Beta\%2C_and_Gamma_Decay (accessed on 9 February 2021).

36. Gamma Rays Compared with X-rays for Radiographic Inspection. Available online: https://www.twi-global.com/technical-kno wledge/faqs/faq-what-are-the-advantages-and-disadvantages-of-gamma-rays-when-compared-with-x-rays-for-radiograph ic-inspection.aspx (accessed on 9 February 2021).

37. Bikit, I. Gamma Rays: Technology, Applications and Health Implications; Nova Science Publishers: Hauppauge, NY, USA, $2013 ;$ p. 413.

38. McKeen, L.W. (Ed.) 10-Elastomers and Rubbers. In The Effect of UV Light and Weather on Plastics and Elastomers (Fourth Edition); Plastics Design Library; William Andrew Publishing: Oxford, UK, 2019; pp. 279-359. ISBN 978-0-12-816457-0.

39. Upadhya, K. A Review of: “Fundamentals of Plasma Chemistry and Technology” By H.V. Boenig Technomic Publishing Co. Lancaster, PA 17604417 Pages, Hard Cover, 1988. Mater. Manuf. Process. 1991, 6, 557-559. [CrossRef] 
40. Henniker Plasma Atmospheric Plasma Treatment Explained. Available online: https://plasmatreatment.co.uk/pt/plasma-tech nology-overview/atmospheric-plasma-treatment (accessed on 5 February 2021).

41. Sivaram, S. Fundamentals of Plasma Chemistry. In Chemical Vapor Deposition: Thermal and Plasma Deposition of Electronic Materials; Sivaram, S., Ed.; Springer: Boston, MA, USA, 1995; pp. 119-143. ISBN 978-1-4757-4751-5.

42. Plasma Technology. What Is Plasma? I Plasmatreat. Available online: https://www.plasmatreat.com/plasma-technology/what-i s-plasma.html (accessed on 9 February 2021).

43. ScienceDirect Topics Microwave Irradiation-An Overview. Available online: https://www.sciencedirect.com/topics/medicineand-dentistry/microwave-irradiation (accessed on 5 February 2021).

44. Lucas, J. Live Science Contributor. February 9 2018. What Are Microwaves? Available online: https://www.livescience.com/50 259-microwaves.html (accessed on 10 February 2021).

45. Utracki, L.A. Head Polymer Blends program. Plasma Deposition, Treatment, And Etching Of Polymers. Mater. Manuf. Process. 1993, 8, 385-390. [CrossRef]

46. Bagher, A.M. Advantages of Gamma Radiation in Science and Industry. J. Adv. Phys. 2014, 3, 97-103. [CrossRef]

47. Martínez-Barrera, G.; Ávila-Córdoba, L.I.; Martínez-López, M.; Herrera-Sosa, E.S.; Vigueras-Santiago, E.; Barrera-Díaz, C.E.; González-Rivas, F.; González-Rivas, N. Gamma Radiation as a Recycling Tool for Waste Materials Used in Concrete. Evol. Ioniz. Radiat. Res. 2015. [CrossRef]

48. Burillo, G.; Clough, R.L.; Czvikovszky, T.; Guven, O.; Le Moel, A.; Liu, W.; Singh, A.; Yang, J.; Zaharescu, T. Polymer Recycling: Potential Application of Radiation Technology. Radiat. Phys. Chem. 2002, 64, 41-51. [CrossRef]

49. ScienceDirect Topics Surface Activation-An Overview. Available online: https://www.sciencedirect.com/topics/engineering/s urface-activation (accessed on 11 December 2019).

50. Gupta, S.K.; Singh, P.; Singh, R.; Kumar, R. Impact of Swift Heavy Ions and Gamma Radiation upon Optical, Structural, and Chemical Properties of Polypropylene Polymer Films. Adv. Polym. Technol. 2015, 34. [CrossRef]

51. Albano, C.; Reyes, J.; Ichazo, M.; González, J.; Hernández, M.; Rodríguez, M. Mechanical, Thermal and Morphological Behaviour of the Polystyrene/Polypropylene (80/20) Blend, Irradiated with $\gamma$-Rays at Low Doses (0-70 KGy). Polym. Degrad. Stab. 2003, 80, 251-261. [CrossRef]

52. Faldini, S.B.; Terence, M.C.; Miranda, L.F.; Munhoz, A.H.; Domingues, L.S.; Coghetto, G. Characterization Of Crumb Rubber Modified By Gamma Radiation; INIS.IAEA: Vienna, Austria, 2013; p. 11.

53. Martínez-Barrera, G.; del Coz-Díaz, J.J.; Álvarez-Rabanal, F.P.; López Gayarre, F.; Martínez-López, M.; Cruz-Olivares, J. Waste Tire Rubber Particles Modified by Gamma Radiation and Their Use as Modifiers of Concrete. Case Stud. Constr. Mater. 2020 12, e00321. [CrossRef]

54. Chen, H.-B.; Wang, P.-C.; Liu, B.; Zhang, F.-S.; Ao, Y.-Y. Gamma Irradiation Induced Effects of Butyl Rubber Based Damping Material. Radiat. Phys. Chem. 2018, 145, 202-206. [CrossRef]

55. Newton, R.G. Mechanism of Exposure-Cracking of Rubbers. With a Review of the Influence of Ozone. Rubber Chem. Technol. 1945, 18, 504-556. [CrossRef]

56. Iwase, Y.; Shindo, T.; Kondo, H.; Ohtake, Y.; Kawahara, S. Ozone Degradation of Vulcanized Isoprene Rubber as a Function of Humidity. Polym. Degrad. Stab. 2017, 142, 209-216. [CrossRef]

57. Lippens, P. 3-Low-pressure cold plasma processing technology. In Plasma Technologies for Textiles; Woodhead Publishing Series in Textiles; Shishoo, R., Ed.; Woodhead Publishing: Sawston, UK; Cambridge, UK, 2007; pp. 64-78. ISBN 978-1-84569-073-1.

58. Liu, J.; Liu, P.; Zhang, X.; Lu, P.; Zhang, X.; Zhang, M. Fabrication of Magnetic Rubber Composites by Recycling Waste Rubber Powders via a Microwave-Assisted in Situ Surface Modification and Semi-Devulcanization Process. Chem. Eng. J. 2016, 295, 73-79. [CrossRef]

59. Martin, D.; Ighigeanu, D.; Mateescu, E.; Craciun, G.; Ighigeanu, A. Vulcanization of Rubber Mixtures by Simultaneous Electron Beam and Microwave Irradiation. Radiat. Phys. Chem. 2002, 65, 63-65. [CrossRef]

60. Phetarporn, V.; Loykulnant, S.; Kongkaew, C.; Seubsai, A.; Prapainainar, P. Composite Properties of Graphene-Based Materials/Natural Rubber Vulcanized Using Electron Beam Irradiation. Mater. Today Commun. 2019, 19, 413-424. [CrossRef]

61. Yang, X.; Shen, A.; Li, B.; Wu, H.; Lyu, Z.; Wang, H.; Lyu, Z. Effect of Microwave-Activated Crumb Rubber on Reaction Mechanism, Rheological Properties, Thermal Stability, and Released Volatiles of Asphalt Binder. J. Clean. Prod. 2020, 248, 119230. [CrossRef]

62. Liang, M.; Xin, X.; Fan, W.; Ren, S.; Shi, J.; Luo, H. Thermo-Stability and Aging Performance of Modified Asphalt with Crumb Rubber Activated by Microwave and TOR. Mater. Des. 2017, 127, 84-96. [CrossRef]

63. Chtourou, H.; Riedl, B.; Kokta, B.V. Surface Modification of Polyethylene Pulp Fiber by Ozone Treatment. An Analytical and Thermal Characterization. Polym. Degrad. Stab. 1994, 43, 149-156. [CrossRef]

64. Martín-Martínez, J.M.; Romero-Sánchez, M.D. Strategies to Improve the Adhesion of Rubbers to Adhesives by Means of Plasma Surface Modification. Eur. Phys. J. Appl. Phys. 2006, 34, 125-138. [CrossRef]

65. Ortiz-Magán, A.B.; Pastor-Blas, M.M.; Ferrándiz-Gómez, T.P.; Morant-Zacarés, C.; Martín-Martínez, J.M. Surface Modifications Produced by $\mathrm{N}_{2}$ and $\mathrm{O}_{2}$ RF Plasma Treatment on a Synthetic Vulcanized Styrene-Butadiene Rubber. Plasmas Polym. 2001, 6, 81-105. [CrossRef] 
66. Xiaowei, C.; Sheng, H.; Xiaoyang, G.; Wenhui, D. Crumb Waste Tire Rubber Surface Modification by Plasma Polymerization of Ethanol and Its Application on Oil-Well Cement. Appl. Surf. Sci. 2017, 409, 325-342. [CrossRef]

67. Li, J.; Xiao, F.; Amirkhanian, S.N. High Temperature Rheological Characteristics of Plasma-Treated Crumb Rubber Modified Binders. Constr. Build. Mater. 2020, 236, 117614. [CrossRef] 